\title{
Gammarus fossarum as a sensitive tool to reveal residual toxicity of treated wastewater effluents
}

\author{
Adriana Wigh ${ }^{\text {a }}$, Olivier Geffard ${ }^{\mathrm{b}}$, Khedidja Abbaci $^{\mathrm{b}}$, Adeline Francois ${ }^{\mathrm{b}}$, Patrice Noury ${ }^{\mathrm{b}}$, Alexandre Bergé ${ }^{\mathrm{c}}$, \\ Emmanuelle Vulliet ${ }^{\mathrm{c}}$, Bruno Domenjoud ${ }^{\mathrm{d}}$, Adriana Gonzalez-Ospina ${ }^{\mathrm{d}}$, Sylvie Bony ${ }^{\mathrm{a}}$, Alain Devaux ${ }^{\mathrm{a}, *}$ \\ a ENTPE, INRA, CNRS UMR 5023 LEHNA, rue Maurice Audin, 69518 Vaulx-en-Velin Cedex, France \\ b Irstea - Groupement de Lyon, Unité de recherche Milieux Aquatiques, Ecologie et Pollutions (MAEP), 5 rue de la Doua, 69626 Villeurbanne Cedex, France \\ c Université de Lyon, Institut des Sciences Analytiques, UMR5280 CNRS, Université Lyon 1, ENS-Lyon, 5 rue de la Doua, 69100 Villeurbanne, France \\ d SUEZ International - Treatment Infrastructure, Wastewater Technical Division, Degrémont, 183 avenue du 18 juin 1940, 92508 Rueil-Malmaison, France
}

\begin{abstract}
Wastewater treatment plants (WWTPs) are one of the main sources of freshwater pollution eventually resulting in adverse effects in aquatic organisms. Treated effluents can contain many micropollutants at concentrations often below the limit of chemical quantification. On a regulatory basis, WWTP effluents have to be non-toxic to the aquatic environment, wherefore not only chemical abatement but also ecotoxicological evaluation through relevant bioassays is required. Standardized bioassays currently used are often not sensitive enough to reveal a residual toxicity in treated effluents. Therefore, attention must be paid to the development of better-adapted approaches implementing more sensitive organisms and relevant endpoints. In this study, the toxicity of two differently treated effluents (activated sludge treated effluents with and without ozonation) towards the ecologically relevant species Gammarus fossarum was evaluated. Organism fitness traits such as reproduction and sperm DNA integrity were followed in exposed organisms. In complement, enzymatic biomarkers were measured indicating the presence of neurotoxic compounds (acetylcholinesterase activity), the presence of pathogens likely to increase the toxic effects of chemical compounds (phenol-oxidase activity), and the presence of toxic compounds inducing detoxification mechanisms (glutathione-S-transferase activity). Enzymatic activities were not modified, but significant sub-lethal effects were observed in exposed organisms. In both effluents, females showed a retarded molt cycle, a reduced fecundity and fertility, and $>90 \%$ of developed embryos exhibited developmental malformations. In addition, a slight but significant genotoxic effect was measured in gammarid sperm. In a whole, no difference in toxicity was found between both effluents. Coupling reproduction impairment and genotoxicity assessment in Gammarus fossarum seems to be a valuable and sensitive tool to reveal residual toxicity in effluents containing a mixture of micropollutants at very low concentrations. Finally, a direct relationship between the observed toxic responses and the quantified micropollutant concentrations could not be evidenced.
\end{abstract}

\footnotetext{
* Corresponding author.

E-mail address: alain.devaux@entpe.fr (A. Devaux).
} 


\section{Introduction}

To date, wastewater treatment plants (WWTPs) continuously discharge micropollutants of concern, which can have biological adverse effects on non-target organisms in receiving ecosystems (Oehlmann et al., 2006; Besse et al., 2013; Morrissey et al., 2015; Petrie et al., 2015). WWTPs were designed and are being constantly improved to reduce efficiently the most part of contaminants, but conventional biological WWTP treatments are not effective to remove some biologically refractory micropollutants (Schwarzenbach et al., 2006; Wick et al., 2009). The Directive 2013/39/EU (European Commission, 2013) supports wastewater treatment plant authorities to develop and use new treatment technologies to reduce the potential hazard of treated effluents towards the aquatic environment. Since effluents should be shown as non-toxic for aquatic flora and fauna before entering receiving waters, standardized toxicity tests using algae, daphnids or fish are required by the European Commission (2000) to evaluate residual toxicity in treated effluents. Effluents can contain many micropollutants at very low concentrations after treatment and it has been shown that standardized bioassays might underestimate effects or might not be sensitive enough to reveal residual toxicity (Kümmerer, 2009; Wigh et al., 2016). Although concentrations of residual compounds are generally in the $\mathrm{ng} / \mathrm{L}$ range, they still might impair organism fitness under chronic exposure and so the long-term ecological state (Fent et al., 2006; Newman and Clements, 2008). Berger et al. (2016) showed that chemicals were likely to induce effects in the environment at concentrations much lower than those based on laboratory experiments. Moreover, extrapolating single compound toxicity, generally assessed in the laboratory, to field-situations may underestimate the actual impact, because of possible pollutant interactions due to the chemical complexity of effluents and thus of receiving water bodies (Silva et al., 2002). Therefore, special attention must be paid for approaches on sensitive species and bioassays allowing long-term exposure and the measurement of relevant endpoints related to the fitness of organisms.

Gammarids as detritivorous species play an important role in the trophic food chain of the aquatic environment. They decompose organic matter and serve as prey for amphibians, insects, flatworms, other crustaceans such as crabs and crayfish, and fish (MacNeil et al., 2002). Gammarids have been shown as very sensitive to pollution, in particular from wastewaters (Peschke et al., 2014; Schirling et al., 2005; Schneider et al., 2015). They have been used in various studies for toxicity evaluation of river waters and effluents through in situ exposure or mesocosm study, by measuring toxicity endpoints such as reproduction, growth impairment and genotoxicity (Bundschuh and Schulz, 2011; Lacaze et al., 2011c; Coulaud et al., 2015). Alterations in reproduction endpoints such as molting cycle, fertility and fecundity may be caused by various pollutants in the effluents and can result in population dynamics impairment (Mazurova et al., 2010; Coulaud et al., 2015; Schneider et al., 2015). Pollutant genotoxicity can lead to organism fitness impairment in particular when affecting gametes. Hence it has been used in many studies as a sensitive sub-lethal endpoint to assess the toxicity of environmental samples (Stalter et al., 2010; Devaux et al., 2011; Lacaze et al., 2011c; Magdeburg et al., 2014). Spermatozoa of Gammarus fossarum were found to be the most sensitive cell type for genotoxicity evaluation compared to hemocytes and oocytes (Lacaze et al., 2011a).

Effluents contain a range of pesticides known to block acetylcholinesterase activity (AChE) in chemical synapses leading to neurotoxic effects due to an overactivation of postsynaptic acetylcholine receptors.
Measurement of AChE inhibition has been successfully used as a biomarker for the presence of neurotoxic compounds, in particular in gammarids (Fulton and Key, 2001; Xuereb et al., 2009a). The detoxification enzyme glutathione S-transferase activity (GST activity) has been shown to increase with oxidative stress in organisms exposed to a large array of contaminants such as nitro compounds, organophosphates and organochlorines, possibly present in treated wastewaters (Hyne and Maher, 2003; Karaouzas et al., 2011; Turja et al., 2014). Moreover, treated effluents contain various bacteria and parasites that can enhance some adverse effects of pollutants towards organisms. Phenol-oxidase is an important enzyme for arthropod immune defense by triggering encapsulation and melanin deposition to prevent microbial growth (Sugumaran, 2002). A strong synergistic toxic effect was shown in Enallagma cyathigerum larvae exposed to the organophosphate insecticide chlorpyrifos (acetylcholinesterase inhibitor) and to the non-pathogenic bacterium Escherichia coli (Janssens and Stoks, 2013).

The aim of the present study was to evaluate the residual chronic toxicity of two differently treated WWTP effluents, by measuring endpoints regarding genotoxicity, neurotoxicity, biotransformation, reproduction and immune defense in gammarid Gammarus fossarum caged in effluent output.

\section{Materials and methods}

\subsection{Gammarid sampling and acclimatization}

The sampling site La Tour du Pin (Isère, France. $45^{\circ} 33^{\prime} 54^{\prime \prime} \mathrm{N} 5^{\circ} 26^{\prime} 40^{\prime \prime}$ E) is located in an unpolluted upstream part of the Bourbre River, where the freshwater amphipod Gammarus fossarum is found at a very high population density (Lacaze et al., 2011a). Gammarids (about $8 \mathrm{~mm}$ in size) were collected and let to acclimatize for 12 days in the laboratory in a mixture of well and osmosed waters in standardized conditions: temperature of $12 \pm 1{ }^{\circ} \mathrm{C}, \mathrm{pH} 7.6 \pm 0.2$ and a conductivity of $600 \pm$ $50 \mu \mathrm{S} / \mathrm{cm}$. Oxygen saturation (>90\%) was ensured with an aeration pump. Photoperiod was maintained at $16 \mathrm{~h}$ light/8 h dark. Gammarids were fed ad libitum on black alder leaves (Alnus glutinosa) and supplied once a week with freeze-dried Tubifex worms.

\subsection{Pilot plant description}

In situ exposure of gammarids was conducted in a pilot wastewater treatment plant in Bellecombe (Haute-Savoie, France). The capacity of the two pilot treatment lines was $60 \mathrm{~L} / \mathrm{h}$ with $23 \mathrm{~h}$ of hydraulic contact time. The activated sludge biological treatments were operated in order to achieve a full nitrification at minimal sludge age. The concentration of sludge in the aeration tanks was $2-3 \mathrm{~g} / \mathrm{L}$. The treatment lines were fed with a mixture of raw urban and hospital wastewater at a ratio of $50 \% \mathrm{v} / \mathrm{v}$ with average total suspended solids (TSS), chemical oxygen demand (COD) and $\mathrm{N}-\mathrm{NH}_{4}$ concentration of $139 \mathrm{mg} / \mathrm{L}, 614 \mathrm{mg} / \mathrm{L}$ and $41 \mathrm{mg} / \mathrm{L}$, respectively. Gammarids were exposed to an effluent treated with conventional activated sludge (CAS) and to an effluent treated with conventional activated sludge combined with the ozonation of the mixed liquor in the recirculation loop $\left(\mathrm{CASO}_{3}\right.$ loop$)$. The specific transferred ozone dose, expressed per volume of feeding effluent was $9.4 \mathrm{mg}$ of ozone per liter (Fig. 1). 


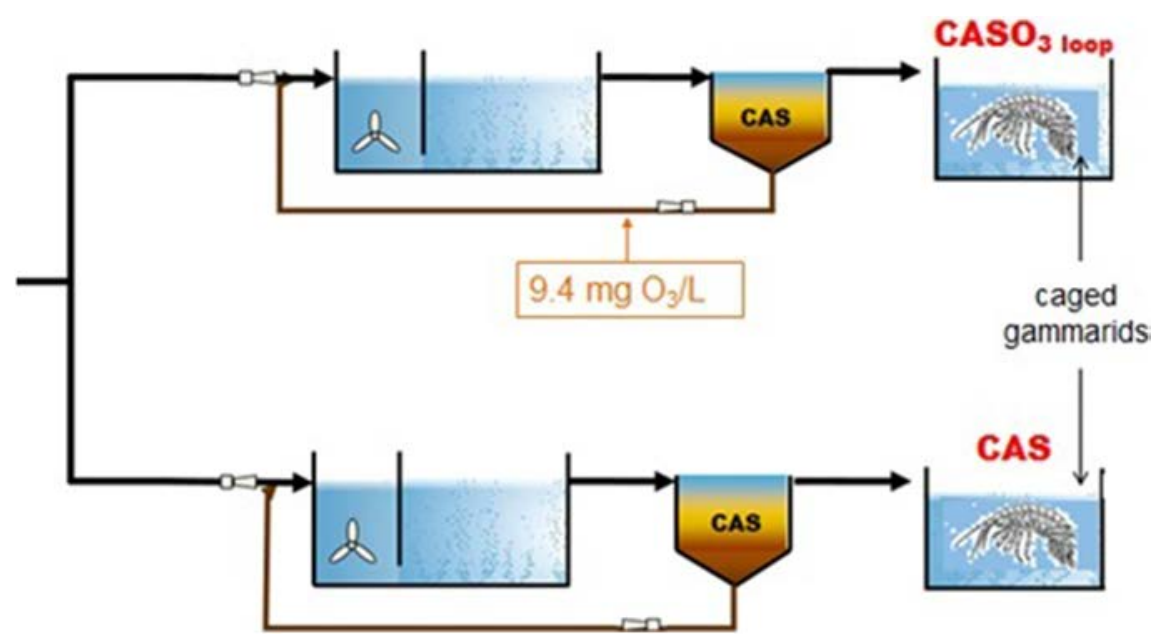

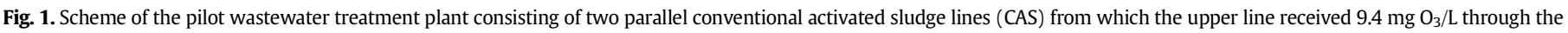
recirculating sludge loop $\left(\mathrm{CASO}_{3}\right.$ loop$)$. Gammarids were caged in aerated tanks placed at the end of treatment lines CAS and CASO ${ }_{3}$ loop.

\subsection{Effluent characterization:}

$\mathrm{CASO}_{3}$ loop effluent and CAS effluent exhibited very similar physicochemical characteristics (Table 1 ).

\subsection{Gammarid exposure}

Sufficient oxygenation (90\% oxygen saturation) of exposed gammarids in the outflow tanks was provided by an aeration device. Gammarids were exposed from June 3rd to June 12th 2015 (10 days exposure). Three replicates, constituted each of 7 couples (each constituted of a guarding male and of a female at the last stage of reproductive cycle i.e. with hatched juveniles in marsupium and visible gonads) were devoted to genotoxicity and reproduction assessment for both controls and exposed groups (Geffard et al., 2010). Additionally, 4 replicates with 20 males each were used for all other biomarker measurements. Organisms were caged in perforated polypropylene tubes $(5 \times 12 \mathrm{~cm})$ containing black alder leaves as a food source, and fixed on holders in a perforated closed bucket, placed in the middle of a tank receiving the treated effluent.

After ten days of exposure, organisms were brought back to the laboratory for endpoints measurement.

\subsection{Control groups}

In the laboratory, two control groups were conducted, the number of replicates and animals being the same than for exposed groups (see above). Control 1 was kept in well water at $18 \pm 1{ }^{\circ} \mathrm{C}, \mathrm{pH} 7.6 \pm 0.2$ and $600 \pm 50 \mu \mathrm{S} / \mathrm{cm}$. The temperature was adapted to in situ exposure conditions since molting cycle is temperature dependent and sexual

Table 1

Physico-chemical parameters for $\mathrm{CASO}_{3}$ loop $=$ effluent treated with ozonated conventional activated sludge $\left(9.4 \mathrm{mg} \mathrm{O}_{3} / \mathrm{L}\right)$ and $\mathrm{CAS}=$ effluent treated with conventional activated sludge. TSS $=$ total suspended solid; $\mathrm{COD}=$ chemical oxygen demand, $(\mathrm{n}=8)$.

\begin{tabular}{llll}
\hline & & CAS & CASO $_{\text {3loop }}$ \\
\hline Temperature & ${ }^{\circ} \mathrm{C}$ & $19.2 \pm 1.3$ & $19.4 \pm 1.6$ \\
Dissolved $\mathrm{O}_{2}$ & $\mathrm{mg} / \mathrm{L}$ & $8.6 \pm 0.2$ & $8.4 \pm 0.3$ \\
$\mathrm{pH}$ & & $7.87 \pm 0.34$ & $7.85 \pm 0.24$ \\
Conductivity & $\mu \mathrm{S} / \mathrm{cm}$ & $1675 \pm 126$ & $1675 \pm 126$ \\
$\mathrm{TSS}$ & $\mathrm{mg} / \mathrm{L}$ & $6 \pm 5$ & $6 \pm 3$ \\
$\mathrm{COD}$ & $\mathrm{mg} \mathrm{O} / \mathrm{L}$ & $32 \pm 9.9$ & $34 \pm 10.1$ \\
$\mathrm{~N}-\mathrm{NH}_{4}$ & $\mathrm{mg} / \mathrm{L}$ & $<0.1$ & $<0.1$ \\
$\mathrm{~N}-\mathrm{NO}_{2}$ & $\mathrm{mg} / \mathrm{L}$ & $0.06 \pm 0.02$ & $0.14 \pm 0.14$ \\
\hline
\end{tabular}

maturity increases with temperature (Glazier et al., 1992; Pöckl et al., 2003). A second control group (control 2) was kept in well water at $18 \pm 1{ }^{\circ} \mathrm{C}, \mathrm{pH} 7.6 \pm 0.2$ and at a conductivity of $1700 \pm 50 \mu \mathrm{S} / \mathrm{cm}$ comparable to that of effluents, to check for possible toxic effects on gammarids due to osmoregulation impairment (Cornet et al., 2009). Water conductivity for control 2 was adjusted by adding $60 \mathrm{mg} / \mathrm{L} \mathrm{CaCl}_{2}$, $2 \mathrm{H}_{2} \mathrm{O}, 900 \mathrm{mg} / \mathrm{L} \mathrm{NaCl}, 40 \mathrm{mg} / \mathrm{L} \mathrm{NA}_{2} \mathrm{HPO}_{4}, 2 \mathrm{H}_{2} \mathrm{O}, 30 \mathrm{mg} / \mathrm{L} \mathrm{MgCL} 2$, $40 \mathrm{mg} / \mathrm{L} \mathrm{KCl}$. Oxygen saturation was ensured with an aeration pump and photoperiod was maintained at $16 \mathrm{~h}$ light/ $8 \mathrm{~h}$ dark.

\subsection{Reproduction and embryo development}

According to Geffard et al. (2010), female molting stages, number of oocytes in ovaries and developmental stages of embryos found in the marsupium were evaluated to determine the impact on reproduction. Gammarus fossarum undergoes six molting stages, which are defined as $\mathrm{A}$ and $\mathrm{B}$ for the post-molt stage, $\mathrm{C} 1$ and $\mathrm{C} 2$ for the inter-molt stage and D1 and D2 for the pre-molt stage (Fig. 2).

Maturation of new oocytes occurs concurrently with embryonic development during the molting cycle. In a normal undisrupted cycle, each molting stage is characterized by one embryonic stage (Fig. 2). In post-molt (A-B) females, newly fertilized embryos are present in the marsupium pouch (stage 1 ). Embryos in stage 2 have a comma shape and are present in molt-stage $\mathrm{C} 1$ females. Embryonic development stage 3 corresponds to stage $\mathrm{C} 2$ female and the embryo developed a cephalothorax and segmented appendages. At stage 4, the eye and appendages are fully developed and the embryos at this stage occur in molting stage D1 females. When females switch to molting stage D2, the fully developed embryos (stage 5) hatch. The mean number of oocytes normalized by female size decreases with the molting cycle, and from molting stage C2 it stays stable and normally comparable to the number of embryos in the marsupium. The number of oocytes can be an indicator of the embryos produced in the marsupium for the next reproductive/molting cycle. C2 and D1 stages are the longest lasting ones where possibly occurring embryonic developmental abnormalities are at best observed. Number of oocytes and number of embryos and embryo developmental stages are determined in these two molting stages $\mathrm{C} 2$ and D1. For determining embryonic development stages and probable anomalies, embryos were released from the marsupium with fine forceps, placed on a slide, immersed in a drop of water and observed under a binocular light microscope. The number of embryos per female normalized according to female size ( $\mathrm{Ne}$ ), embryonic stages and developmental abnormalities in embryos were measured. Observed abnormalities were edema, irregular cleavages and necrosis, enlargement or 


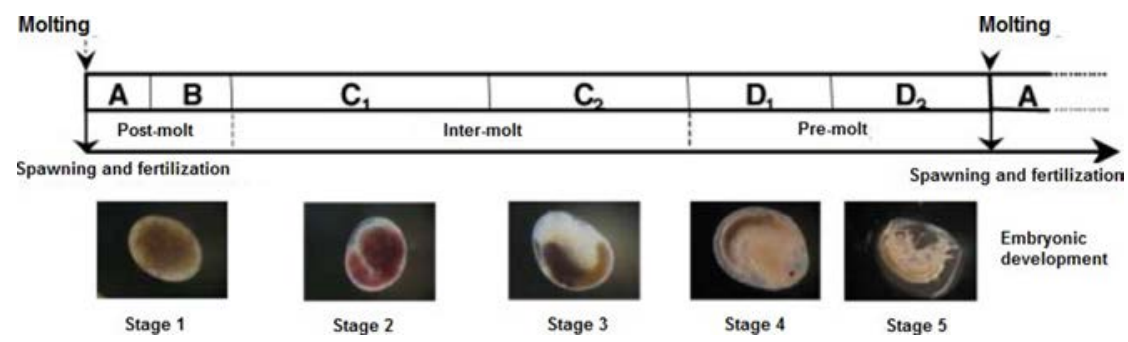

Fig. 2. Molting stages (A to D2) and corresponding embryonic developmental stages 1 to 5 (according to Geffard et al., 2010).

non-specific malformations as illustrated in Lacaze et al. (2011c) and were quantified as an overall abnormality percentage.

\subsection{Genotoxicity in sperm}

The genotoxic potential of the effluents was determined by the assessment of the primary DNA damage level in spermatozoa using the comet assay carried out according to Lacaze et al. (2010). At the end of exposure, 10 mature males per treatment which have been exposed in precopula stage were chosen. The cephalon was cut off with microscissors and caeca were removed from the thorax. Then, the dorsal and ventral cuticle were excised and the gonads, mostly surrounded by orange lipid drops, were collected and dilacerated into $200 \mu \mathrm{L}$ microtube containing $20 \mu \mathrm{L}$ cold phosphate-buffer-saline (PBS) and stored on ice until comet assay processing. Since the dissection took some time and in order to prevent cell degradation, comet assay was carried out as soon as 3 sperm samples were prepared. Each cell suspension was equally mixed $(50 \% \mathrm{~V} / \mathrm{V})$ with $37^{\circ} \mathrm{C}$ heated low melting point agarose gel $(1 \%)$ and $40 \mu \mathrm{L}$ of this mixture were laid on a frosted microscope slide pre-coated with $0.8 \%$ agarose (sperm from each male provided 2 gels per slide) and then covered with a cover-slide. After $10 \mathrm{~min}$ at $4{ }^{\circ} \mathrm{C}$, the cover-slides were gently removed. Slides were covered with the lysis solution $\left(2.5 \mathrm{M} \mathrm{NaCl}, 100 \mathrm{mM} \mathrm{Na}_{2}\right.$ EDTA, $10 \mathrm{mM}$ Tris- $\mathrm{HCl}, 1 \%$ Triton X-100 and 10\% DMSO) and kept for $18 \mathrm{~h}$ at $4{ }^{\circ} \mathrm{C}$ in the dark. Afterwards, slides were placed in the electrophoresis tank filled with the electrophoresis solution ( $300 \mathrm{mM} \mathrm{NaOH}, 1 \mathrm{mM}$ EDTA) and left for $40 \mathrm{~min}$ for DNA unwinding. Then, electrophoresis was conducted at $0.7 \mathrm{~V} / \mathrm{cm}$ and $300 \mathrm{~mA}$ for $24 \mathrm{~min}$. The negatively charged DNA migrates through the gel to the anode resulting in a so-called comet tail when DNA strand breaks occur. After electrophoresis, slides were washed 3 times for $5 \mathrm{~min}$ with a neutralization buffer $(0.4 \mathrm{mM}$ Tris- $\mathrm{HCl})$ and dehydrated in $100 \%$ ethanol for 20 min and let dry at room temperature. For DNA damage scoring, slides were coated with $25 \mu \mathrm{L}$ of a $0.02 \%$ ethidium bromide solution. Each slide was examined through a fluorescence microscope (Axioskop 40, Zeiss Ltd.). Image analysis was performed with the Comet 4.0 software (Perceptive Instruments Ltd.). For each exposed gammarid, tail \% intensity (TI, \% DNA in comet tail) of $2 \times 50$ randomly selected cells was measured. However, some males did not provide enough spermatozoa, thus the total number of gels scored for each treatment varied.

\subsection{Neurotoxicity, immune defense and detoxification activity}

For acetylcholinesterase (AChE), glutathione s-transferase (GST) and phenol oxidase (PO) activity measurement, in toto homogenates of five male gammarids were prepared ( 15 to $20 \mathrm{mg}$ per male, resulting in a total mass of 80 to $100 \mathrm{mg}$ ). Gammarus fossarum whole bodies were homogenized in 1:10 (w:v) ice-cold phosphate buffer ( $100 \mathrm{mM} \mathrm{pH} \mathrm{7.8)}$ containing $0.1 \%$ Triton X-100, with an Ultra-Turrax ${ }^{\circledR}$ T25 basic $(24,000 \mathrm{rpm}$ for $35 \mathrm{~s})$. Then, homogenates were centrifuged at $4{ }^{\circ} \mathrm{C}$ for $15 \mathrm{~min}$ at $9000 \mathrm{~g}$ and the supernatant (post-mitochondrial fraction or S9) was conserved at $4{ }^{\circ} \mathrm{C}$ until enzymatic measurements. All enzymatic reactions were followed at room temperature in 96-well microplates.
A decrease in acetylcholinesterase activity was assigned as a biomarker of neurotoxicity (Fulton and Key, 2001; Xuereb et al., 2009a). AChE activity was determined according to Ellman et al. (1961) adapted to microplates (Xuereb et al., 2009a). In a 96-well microtiter plate, $20 \mu \mathrm{L}$ of $0.0076 \mathrm{M}$ (final concentration) dithiobisnitrobenzoate, $20 \mu \mathrm{L}$ of S9 and $330 \mu \mathrm{L}$ of phosphate buffer ( $0.1 \mathrm{M}$ final concentration) and $10 \mu \mathrm{L}$ of acetylthiocholine iodide solution were added. Hydrolysis to the yellow product 5-thio-2-nitro-benzoic-acid was measured at $405 \mathrm{~nm}$ in a spectrophotometer (SafireR spectrofluorimeter microplate reader, TECAM; Trappes, France) every $60 \mathrm{~s}$ for at least $3 \mathrm{~min}$. AChE activity was expressed as nmoles of substrate hydrolyzed per minute. Xuereb et al. (2009a) showed that natural variation of structural protein contents in female Gammarus fossarum related to physiological changes as the reproductive status, caused variability in AChE activity and therefore to an under- or over-estimation of the effect. According to the authors, variation in AChE activity is negligible in males with a weight between 15 and $20 \mathrm{mg}$ and therefore male gammarids of this weight were used for AChE measurement in the present study. AChE activity was considered significantly inhibited when reaching a $12 \%$ lower value than that of control group. If AChE activity was significantly inhibited compared to the control, this was considered as resulting from exposure to neurotoxic compounds (Xuereb et al., 2009a).

GST activity was measured according to Habig et al. (1976) in 96well microplates by adding $170 \mu \mathrm{L}$ of $2.2 \mathrm{mM}$ reduced glutathione (final concentration), $10 \mu \mathrm{L}$ of $38 \mathrm{mM}$ 1-chloro-2.4-dinitrobenzene (final concentration), $150 \mu \mathrm{L}$ of $0.1 \mathrm{M}$ phosphate buffer (final concentration) and $20 \mu \mathrm{L}$ of the S9 fraction per well. GST activity was measured in a spectrophotometer (SafireR spectrofluorimeter microplate reader, TECAM; Trappes, France) at $340 \mathrm{~nm}$ every $30 \mathrm{~s}$ for at least $3 \mathrm{~min}$. GST activity was expressed as nmoles of substrate hydrolyzed per minute per mg of protein. Protein content was measured according to Lowry et al. (1951).

Phenol oxidase activity was measured according to Janssens and Stoks (2013), adapted for 96-well microtiter plates. Eighty microliters of $5 \mathrm{mM}$ phosphate buffer (final concentration) and $15 \mu \mathrm{L}$ of S9 were added to each well. Then, $5 \mu \mathrm{L}$ of chymotrypsin solution $(5 \mathrm{mg} / \mathrm{mL}$ dissolved in ultra-pure water) were added and incubated for $5 \mathrm{~min}$ at room temperature to convert all pro-enzyme prophenoloxidase into phenoloxidase. Afterwards, $100 \mu \mathrm{L}$ of 3.4-dihydroxy-L-phenylalanine $(1.97 \mathrm{mg} / \mathrm{mL}$ in PBS) were added and the absorbance of the red colored dopachrome was measured in a spectrophotometer (SafireR spectrofluorimeter microplate reader, TECAM; Trappes, France) at $490 \mathrm{~nm}$ every $30 \mathrm{~s}$ during $6 \mathrm{~min}$ at $30^{\circ} \mathrm{C}$. The phenol oxidase activity was expressed as nmoles of substrate hydrolyzed per minute per mg of protein.

\subsection{Statistical analysis}

Nonparametric rank sum test was used to test effects of exposure conditions on the molting cycle, number of oocytes and of embryos produced. Concerning genotoxicity evaluation, the DNA damage was expressed as the median TI\% value calculated from the number of gels containing enough spermatozoa (i.e. 50) to be properly scored for each condition. Median TI \% values measured in organisms, exposed to each effluent, were compared to the corresponding control 1 and 2 or 
between effluents using a rank sum test. Phenol oxidase, acetylcholinesterase and glutathione $S$-transferase activities measured in gammarids from the different exposure scenarios were compared to the corresponding control groups 1 and 2 using rank sum test. Statistical analyses were conducted with the Graph Pad Prism version 5 for windows (GraphPad software, San Diego, CA, USA).

\subsection{Chemical analysis of effluents}

The technical concept sought to improve biodegradation through ozone application by increasing the speed and the overall efficiency of total micropollutant degradation through ozonation of sludge in recycling loop. Emerging contaminants as low biodegradable pharmaceuticals and surfactants (Baig et al., 2010; Li, 2014; Luo et al., 2014) were monitored in both wastewater effluents CAS and $\mathrm{CASO}_{3}$ loop to compare their efficiency to remove such micropollutants. The pharmaceutical compounds analysed correspond to those regularly measured in the SIPIBEL experimental site, i.e. the field observatory on hospital effluents and urban wastewater treatment located in Bellecombe where the pilot plant was settled (Chonova et al., 2016; Perrodin et al., 2016). These compounds were selected on the basis of their high consumption in hospital and domestic environments, their potential for bioaccumulation and toxic effects. The detergents selected correspond to the most common ones used for industrial (including hospitals) and domestic activities. These micropollutants (Table 2) were dosed by using multi-residual method coupling solid phase extraction (SPE) and liquid chromatography-tandem mass spectrometry. Effluents (a 24 h-composite sample collected June 9th 2015 for each condition) were filtered with glass microfiber filter at $0.7 \mu \mathrm{m}$ then extracted with SPE according to Vulliet et al. (2014) for pharmaceuticals and Bergé et al. (2016) for surfactants. Limit of detection (LD) and of quantification (LQ) for each compound are presented in Table 2.

\section{Results}

\subsection{Chemical analysis of effluents}

Regarding pharmaceutical compounds, ciprofloxacin and ethinylestradiol concentrations remained in all analysed samples below the limit of quantification (Table 3). Salicylic acid, ibuprofen, paracetamol and econazole concentrations were in the same range in CAS and $\mathrm{CASO}_{3}$ loop effluents. The anti-inflammatory drug diclofenac and ketoprofen concentrations, and the beta-blockers propranolol and atenolol concentrations were lower in $\mathrm{CASO}_{3}$ loop effluent than in CAS

Table 2

Limit of detection (LD) and of quantification (LQ) for pharmaceuticals [ng/L] and surfac$\operatorname{tants}[\mu \mathrm{g} / \mathrm{L}]$.

\begin{tabular}{llllll}
\hline Pharmaceuticals & LD & LQ & Surfactants & LD \\
& ng/L & ng/L & & $\begin{array}{l}\text { LQ } \\
\mu \mathrm{g} / \mathrm{L}\end{array}$ \\
\hline Carbamazepine & 0.2 & 0.6 & Comperlan 100 & 0.03 & 0.1 \\
Ciprofloxacin & 11.8 & 35.3 & Triton X-100 & 0.03 & 0.1 \\
Sulfamethoxazole & 2.0 & 5.9 & Incromine SB & 0.07 & 0.2 \\
Salicylic acid & 4.4 & 13.3 & Stepanquat GA 90 & 1.67 & 5 \\
Ibuprofen & 0.2 & 0.5 & BDDAC benzyldodecyldimethyl & 0.08 & 0.24 \\
& & & ammonium chloride & & \\
Paracetamol & 4.1 & 12.2 & BDTAC benzyldimethyltetradecyl & 0.05 & 0.16 \\
& & & ammonium chloride & & \\
Diclofenac & 1.7 & 5 & Lauryl pyridinium & 0.07 & 0.2 \\
Ketoprofen & 3.1 & 9.3 & Sodium 2-ethylhexyl sulfate & 1.67 & 5 \\
Propanolol & 0.2 & 0.6 & Sodium dodecyl sulfate (SDS) & 0.17 & 0.5 \\
Atenolol & 1.4 & 4.1 & LAS C10 & 0.67 & 2 \\
Econazole & 0.4 & 1.1 & LAS C11 & 0.67 & 2 \\
Ethinylestradiol & 2.4 & 7.3 & LAS C12 & 0.67 & 2 \\
& & & LAS C13 & 0.67 & 2 \\
& & & Texapon N 701 S & 1.67 & 5 \\
& & & Cetyl betaine & 0.03 & 0.1
\end{tabular}

Table 3

Pharmaceutical concentrations measured in CAS effluent treated with conventional activated sludge and in $\mathrm{CASO}_{3}$ loop effluent treated with ozonated conventional activated sludge $\left(9.4 \mathrm{mg} \mathrm{O}_{3} / \mathrm{L}\right) \pm \mathrm{SD}$. LQ $=$ limit of quantification.

\begin{tabular}{llll}
\hline Pharmaceutical & $\begin{array}{l}\mathrm{LQ} \\
{[\mathrm{ng} / \mathrm{L}]}\end{array}$ & $\begin{array}{l}\mathrm{CAS} \\
{[\mathrm{ng} / \mathrm{L}]}\end{array}$ & $\begin{array}{l}\mathrm{CASO}_{3} \text { loop } \\
{[\mathrm{ng} / \mathrm{L}]}\end{array}$ \\
\hline Carbamazepine & 0.6 & $1514 \pm 45$ & $662 \pm 19$ \\
Ciprofloxacin & 35.3 & $<\mathrm{LQ}$ & $<\mathrm{LQ}$ \\
Sulfamethoxazole & 5.9 & $11,560 \pm 2080$ & $4020 \pm 723$ \\
Salicylic acid & 13.3 & $489.6 \pm 0.7$ & $668 \pm 0.9$ \\
Ibuprofen & 0.5 & $31.2 \pm 0.1$ & $51.6 \pm 0.1$ \\
Paracetamol & 12.2 & $31.5 \pm 2.8$ & $49.4 \pm 4.4$ \\
Diclofenac & 5 & $383 \pm 46$ & $175 \pm 21$ \\
Ketoprofen & 9.3 & $53 \pm 2$ & $26.9 \pm 1.3$ \\
Propanolol & 0.6 & $125.4 \pm 5.0$ & $97.8 \pm 3.9$ \\
Atenolol & 4.1 & $496 \pm 10$ & $168.4 \pm 3.4$ \\
Econazole & 1.1 & $4.3 \pm 0.9$ & $3.5 \pm 0.7$ \\
Ethinylestradiol & 7.3 & $<\mathrm{LQ}$ & $<\mathrm{LQ}$ \\
\hline
\end{tabular}

effluent. A similar trend was observed for both sulfamethoxazole and carbamazepine.

The surfactants comperlan 100 , incromine SB, lauryl pyridinium, texapon $\mathrm{N} 701 \mathrm{~S}$ and cetyl betaine were below the limit of quantification in CAS and $\mathrm{CASO}_{3}$ loop effluents (Table 4). Triton X-100, benzyldodecyldimethyl ammonium chloride, benzyldimethyltetradecyl ammonium chloride, sodium 2-ethylhexyl sulfate, sodium dodecyl sulfate and LAS C11 to C13 also remained below their limit of quantification in both CAS and $\mathrm{CASO}_{3}$ loop effluents.

The linear alkylbenzene sulfonate LAS C10 concentration was $9.5 \mu \mathrm{g} /$ $\mathrm{L}$ after CAS and to $10.2 \mu \mathrm{g} / \mathrm{L}$ after $\mathrm{CASO}_{3}$ loop treatment. Stepanquat GA 90 concentration was similar in both treatment lines.

\subsection{Reproduction and embryo development}

The molting cycle is temperature-dependent according to Pöckl (1992) and Pöckl and Timischl (1990). As shown in Table 5, after 10 days of exposure at an average temperature between 18 and $19^{\circ} \mathrm{C}$, $90 \%$ of the females in the control 1 group ( $n=20$ females) were in molt stage $\mathrm{C} 2,5 \%$ in molt stage $\mathrm{C} 1$ and $5 \%$ in molt stage D1 (Table 5). Correspondingly, $90 \%$ of embryos found in the marsupium of control females were at developmental stage 3 and $10 \%$ at stage 4 . One female (5\%) showed a retarded molt cycle (C1) compared to the embryonic stage of embryos present in the marsupium (stage 3 ). In control 2

Table 4

Surfactant concentrations measured in CAS effluent treated with conventional activated sludge and in $\mathrm{CASO}_{3}$ loop effluent treated with ozonated conventional activated sludge $\left(9.4 \mathrm{mg} \mathrm{O}_{3} / \mathrm{L}\right) \pm \mathrm{SD}$. LQ = limit of quantification.

\begin{tabular}{|c|c|c|c|}
\hline Surfactants & $\begin{array}{l}\text { LQ } \\
{[\mu \mathrm{g} / \mathrm{L}]}\end{array}$ & $\begin{array}{l}\text { CAS } \\
{[\mu \mathrm{g} / \mathrm{L}]}\end{array}$ & $\begin{array}{l}\mathrm{CASO}_{3} \\
\text { loop } \\
{[\mu \mathrm{g} / \mathrm{L}]}\end{array}$ \\
\hline Comperlan 100 & 0.1 & $<\mathrm{LQ}$ & $<\mathrm{LQ}$ \\
\hline Triton X-100 & 0.1 & $<\mathrm{LQ}$ & $<\mathrm{LQ}$ \\
\hline Incromine SB & 0.2 & $<$ LQ & $<\mathrm{LQ}$ \\
\hline Stepanquat GA 90 & 5 & $7.5 \pm 0.3$ & $7.1 \pm 0.3$ \\
\hline $\begin{array}{l}\text { Benzyldodecyldimethyl ammonium chloride } \\
\text { (BDDAC) }\end{array}$ & 0.24 & $<\mathrm{LQ}$ & $<\mathrm{LQ}$ \\
\hline $\begin{array}{l}\text { Benzyldimethyltetradecyl ammonium chloride } \\
\text { (BDTAC) }\end{array}$ & 0.16 & $<\mathrm{LQ}$ & $<\mathrm{LQ}$ \\
\hline Lauryl pyridinium & 0.2 & $<\mathrm{LQ}$ & $<\mathrm{LQ}$ \\
\hline Sodium 2-ethylhexyl sulfate & 5 & $<\mathrm{LQ}$ & $<\mathrm{LQ}$ \\
\hline Sodium dodecyl sulfate (SDS) & 0.5 & $<$ LQ & $<\mathrm{LQ}$ \\
\hline LAS C10 & 2 & $\begin{array}{l}9.52 \\
\pm 0.76\end{array}$ & $\begin{array}{l}10.2 \\
\pm 0.8\end{array}$ \\
\hline LAS C11 & 2 & $<\mathrm{LQ}$ & $<\mathrm{LQ}$ \\
\hline LAS C12 & 2 & $<\mathrm{LQ}$ & $<\mathrm{LQ}$ \\
\hline LAS C13 & 2 & $<\mathrm{LQ}$ & $<\mathrm{LQ}$ \\
\hline Texapon N $701 \mathrm{~S}$ & 5 & $<$ LQ & $<$ LQ \\
\hline Cetyl betaine & 0.1 & $<\mathrm{LQ}$ & $<\mathrm{LQ}$ \\
\hline
\end{tabular}


Table 5

Occurrence (\%) of molt stages (AB, C1, C2, D1, D2) and embryonic stages $(1,2,3,4)$ in Gammarus fossarum. Control 1: well water at $18 \pm 1{ }^{\circ} \mathrm{C}, \mathrm{pH} 7.6 \pm 0.2$ and $600 \pm 50 \mu \mathrm{S} / \mathrm{cm}$; Control 2: well water at $18 \pm 1{ }^{\circ} \mathrm{C}, \mathrm{pH} 7.6 \pm 0.2,1700 \pm 50 \mu \mathrm{S} / \mathrm{cm}$; CAS: effluent treated with conventional activated sludge; $\mathrm{CASO}_{3}$ loop: effluent treated with ozonated conventional activated sludge $\left(9.4 \mathrm{mg} \mathrm{O}_{3} / \mathrm{L}\right)$. Minus: stages were not determinable because too many embryonic abnormalities were present or females did not have embryos in marsupium. $\mathrm{n}$ is the number of females evaluated for molt stage.

\begin{tabular}{|c|c|c|c|c|c|c|c|c|c|c|}
\hline \multirow[t]{2}{*}{ Condition } & \multicolumn{6}{|c|}{ Molt stages (\%) } & \multicolumn{4}{|c|}{ Embryonic stages (\%) } \\
\hline & $\mathrm{n}$ & $\mathrm{AB}$ & $\mathrm{C} 1$ & $\mathrm{C} 2$ & D1 & D2 & 1 & 2 & 3 & 4 \\
\hline Control 1 & 20 & 0 & 5 & 90 & 5 & 0 & 0 & 0 & 90 & 10 \\
\hline Control 2 & 14 & 0 & 29 & 71 & 0 & 0 & 0 & 0 & 100 & 0 \\
\hline CAS & 16 & 46 & 53 & 0 & 0 & 0 & - & - & - & - \\
\hline $\mathrm{CASO}_{3}$ loop & 17 & 47 & 41 & 6 & 0 & 6 & - & - & - & - \\
\hline
\end{tabular}

( $\mathrm{n}=14$ females), $71.4 \%$ of females were in molt stage $\mathrm{C} 2$ and $28.6 \%$ in molt stage $\mathrm{C} 1,100 \%$ of embryos were in developmental stage 3 and three females showed a delay in molt cycle although not statistically different compared to control 1 .

After exposure to CAS effluent, $53 \%$ of females $(n=16)$ were at molt stage $\mathrm{C} 1$ and $46 \%$ at molt stage $\mathrm{AB}$. After exposure to $\mathrm{CASO}_{3}$ loop effluent $41 \%$ of females were in molt stage $C 1$ and $47 \%$ of females $(n=17)$ were at molt stage $\mathrm{AB}$. The embryonic stages of embryos present in the marsupium were not determined because too many embryos presented developmental abnormalities. The molt cycle was significantly inhibited in both $\mathrm{CAS}$ and $\mathrm{CASO}_{3}$ loop effluent exposed groups when compared to the control $1(\mathrm{p}<0.001)$ as well as compared to control $2(\mathrm{p}<0.01)$. No difference between CAS and $\mathrm{CASO}_{3}$ loop groups was found.

The number of embryos per female normalized according to female size $(\mathrm{Ne})$ ranged between 1.2 and 4.6 with a median value of 3.6 in control 1 , and $10 \%$ of all counted embryos $(n=279)$ showed developmental abnormalities (Fig. 3A). In control 2 (adapted conductivity), Ne was significantly decreased to a median value of 2.8 (ranging from 0 to 3.7) compared to control 1 ( $p<0.01$ ) but the percentage of embryos exhibiting developmental abnormalities (12\%) was comparable to that of control 1. Ne was significantly reduced in CAS $(p<0.001)$ with a median value of 0.4 embryo per female (minimum 0 to maximum 1.6) compared to control 1 as well as compared to control $2(p<0.05)$. From the total number of embryos $(n=20), 90 \%$ presented developmental abnormalities. Females exposed to $\mathrm{CASO}_{3}$ loop effluent carried between 0 and 1.97 embryos (median 0.5 ), which was significantly different compared to control 1 and control 2 ( $p<0.001$ ), and $96 \%$ of observed embryos $(\mathrm{n}=28)$ exhibited developmental abnormalities. Ne was not significantly different in $\mathrm{CAS}$ or $\mathrm{CASO}_{3}$ loop exposed organisms.
The number of oocytes in females (normalized according to female size) at molt stage C2 or D1 $(n=19)$ ranged between 0 and 4.3 (median value at 2.8 ) in control 1 (Fig. 3B). In control 2 ( $\mathrm{n}=10$ females in molt stage $\mathrm{C} 2$ ), the number of oocytes per female ranged between 0 and 3.2 (median value at 2.6) and did not differ statistically from that of control 1. In $\mathrm{CASO}_{3}$ loop effluent exposure group, only one female was in molt stage $\mathrm{C} 2$ and exhibited 3.8 oocytes, whereas in CAS effluent exposure group none of the females were in $\mathrm{C} 2$ or D1 and therefore no oocyte number could be determined.

\subsection{Genotoxicity assessment}

Primary DNA damage in gammarid sperm (Fig. 4) from control 1 ranged between $0.06 \%$ and $17 \% \mathrm{TI}$ with a median value of $7.3 \%$, and between $2.4 \%$ and $21 \%$ (9.2\% median value) in control 2 , not statistically different compared to amphipods of control 1. Sperm of gammarids exposed to CAS effluent showed a slightly but significantly higher DNA damage level with a median $\mathrm{TI}$ value of $15.5 \%$ (minimum 2 , maximum $25.5)$ compared to that of control 1 ( $p=0.019)$, but not different compared to that of control 2. Tail intensity measured in sperm of gammarids exposed to $\mathrm{CASO}_{3}$ loop effluent (11\% median TI, minimum 3.6, maximum 27.5) was not significantly different compared to those from both controls and from CAS group.

\subsection{Neurotoxicity, immune defense and detoxification activity measurement}

As proposed by Xuereb et al. (2009a), the acetylcholinesterase (AChE) activity was expressed as nmol/min (Fig. $5 \mathrm{~A}$ ). In male gammarids, AChE activity was the same in both controls, $10.3 \mathrm{nmol} / \mathrm{min}$ $\left(\mathrm{Cl}_{95 \%}\right.$ : $\left.[10.1,10.5]\right)$ in control 1 and $11.2 \mathrm{nmol} / \mathrm{min}\left(\mathrm{Cl}_{95 \%}\right.$ : [10.1, 12.3]) in control 2. AChE activity measured in male gammarids exposed to CAS effluent $\left(11.5 \mathrm{nmol} / \mathrm{min}\left(\mathrm{Cl}_{95 \%}\right.\right.$ : $\left.\left.[11.2,11.9]\right)\right)$ was slightly increased compared to control 1 and 2 (11.8\% and $2.9 \%$ increase, respectively), although not statistically different. AChE activity in gammarids exposed to $\mathrm{CASO}_{3}$ loop effluent $\left(10.5 \mathrm{nmol} / \mathrm{min}, \mathrm{Cl}_{95 \%}\right.$ : $\left.[9.8,11.3]\right)$ was not statistically different from that of both controls and of CAS group.

Glutathione S-transferase (GST) activity was in average the same in all exposure groups, $8.2 \mathrm{nmol} / \mathrm{min} / \mathrm{mg}\left(\mathrm{Cl}_{95 \%}\right.$ : $\left.[7.5,9.0]\right)$, $9.1 \mathrm{nmol} / \mathrm{min} / \mathrm{mg}\left(\mathrm{Cl}_{95 \%}\right.$ : [8.7, 9.5]), $8.1 \mathrm{nmol} / \mathrm{min} / \mathrm{mg}\left(\mathrm{Cl}_{95 \%}\right.$ : [7.4, $8.8])$ and $8.4 \mathrm{nmol} / \mathrm{min} / \mathrm{mg}\left(\mathrm{Cl}_{95 \%}\right.$ : [7.5, 9.4]), in control 1, control 2, CAS and $\mathrm{CASO}_{3}$ loop exposed groups, respectively (Fig. 5B). Phenoloxidase (PO) activity measured in Gammarus fossarum from the
A

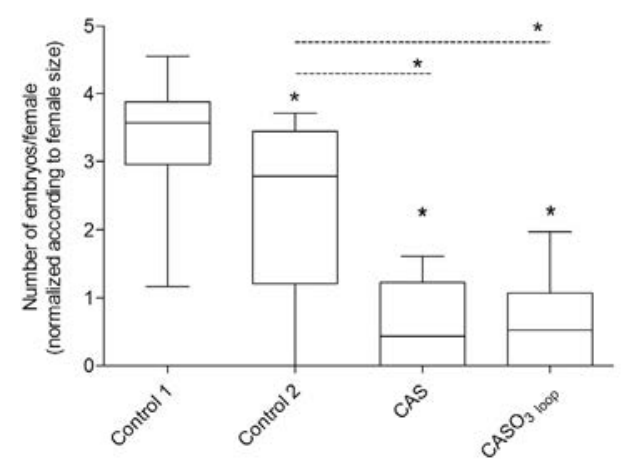

B

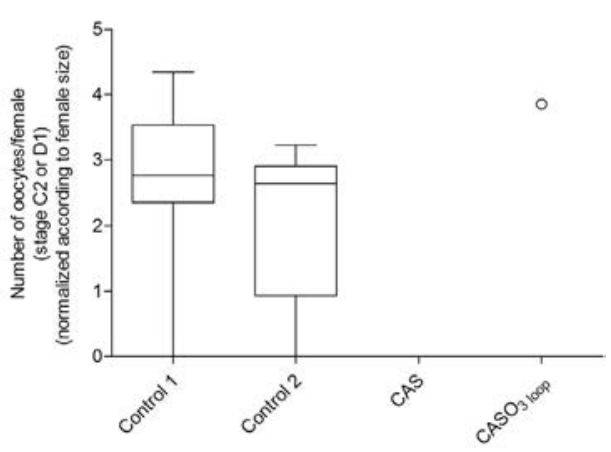

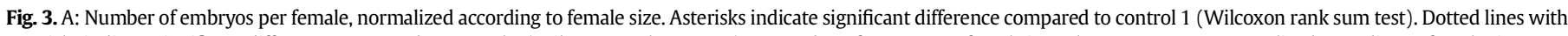

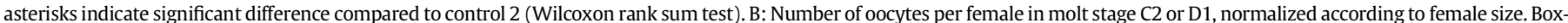

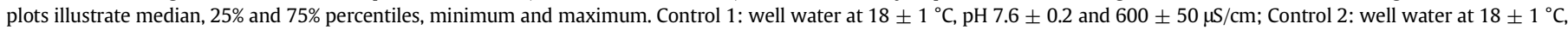

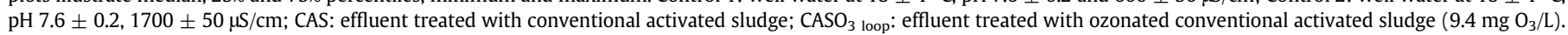
Circle indicates that only one female was in stage C2/D1 . 


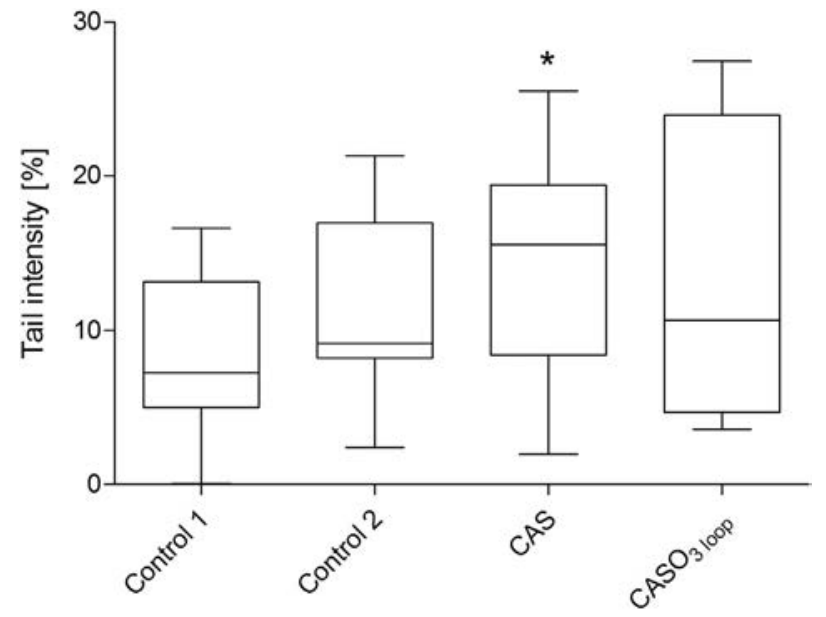

Fig. 4. Genotoxicity evaluation in Gammarus fossarum spermatozoa expressed as tail intensity [TI \%] plotted against exposure conditions. Box-plots illustrate median, 25\% and $75 \%$ percentiles, minimum and maximum. Asterisks indicate significant difference compared to control 1 (Mann-Whitney). Control $1(\mathrm{n}=15)$ : well water at $18 \pm 1{ }^{\circ} \mathrm{C}$, $\mathrm{pH} 7.6 \pm 0.2$ and $600 \pm 50 \mu \mathrm{S} / \mathrm{cm}$; Control $2(\mathrm{n}=11)$ : well water at $18 \pm 1{ }^{\circ} \mathrm{C}$, $\mathrm{pH} 7.6 \pm 0.2,1700 \pm 50 \mu \mathrm{S} / \mathrm{cm}$; CAS $(\mathrm{n}=16)$ : effluent treated with conventional activated sludge; $\mathrm{CASO}_{3}$ loop $(\mathrm{n}=14)$ : effluent treated with ozonated conventional activated sludge $\left(9.4 \mathrm{mg} \mathrm{O}_{3} / \mathrm{L}\right)$. $\mathrm{n}$ : number of gels scored.

different groups remained in the range of $2.3-2.8 \mathrm{nmol} / \mathrm{min} / \mathrm{mg}$ and did not differ statistically from each other (Fig. 5C).

\section{Discussion}

AChE, glutathione-S-transferase and phenol oxidase activities were measured in encaged gammarids as early warning indicators for the presence and effect of neurotoxic compounds, of compounds interfering with detoxification processes and immune defense. No significant effect of effluent was shown whatever the exposure condition and the enzymatic activity. Since PO is involved in the clearance of many different pathogens, it can be suggested that Gammarus fossarum did not suffer from any immune stress and consequently of a possible synergistic effect with residual micropollutants when exposed to CAS or $\mathrm{CASO}_{3}$ loop treated effluents (Braun et al., 1998). Gammarid exposure to CAS and $\mathrm{CASO}_{3}$ loop effluents did not result in an inhibition of AChE activity, arguing for the lack of neurotoxicity of the residual pollutant mixture in treated effluents. The same trend was observed regarding GST activity measured in gammarids exposed to CAS and $\mathrm{CASO}_{3}$ loop effluents that remained close to the control activity. In theory, such biochemical biomarkers reflect the biochemical sublethal changes of an organism exposed to xenobiotics and can be used as early warning systems, since they can identify changes at cellular level before measurable effects are induced in organisms (Hyne and Maher, 2003; Karaouzas et al., 2011). However, biomarker response depends on many factors, among them the characteristics of the pollutant mixture (on a qualitative and quantitative basis), the duration of exposure, the metabolic capacities of organisms exposed, what drives the sensitivity of the assay to reveal toxic events. However, absence of biochemical responses does not mean an absence of sublethal fitness impairing effects, such as a decrease in reproductive output or gamete genotoxicity like in the present study (Domingues et al., 2010).

DNA damage is a relevant sub-lethal endpoint to assess genotoxic compounds often present in wastewaters that may impact the fitness of various aquatic organisms (Chen et al., 2012; Jha, 2008; Magdeburg et al., 2014; Misik et al., 2011). A reference value for DNA damage in spermatozoa of Gammarus fossarum exposed to uncontaminated rivers was determined to be in the range of 2.6-3.5\% TI. During the warm period with water temperatures reaching 16 to $19^{\circ} \mathrm{C}$, reference DNA damage value ranged between 6.5 and $14.9 \% \mathrm{TI}$ (Lacaze et al., 2011a). In the present work, recorded water temperatures were $18^{\circ} \mathrm{C} \pm 1{ }^{\circ} \mathrm{C}$ and basal level of DNA damage in control 1 and 2 was 7.3\% and 9.2\% TI respectively, thus in accordance with Lacaze et al. (2011a). Since DNA damage in gammarids exposed to CAS or $\mathrm{CASO}_{3}$ loop -treated effluent was not significantly different from control 2 (high conductivity), it cannot be excluded that the high conductivity of $1700 \mu \mathrm{S} / \mathrm{cm}$ may have contributed to the significant genotoxicity observed in CAS-exposed gammarids. It has to be stressed that the genotoxic effect observed remained low and was even no more significant when compared to control 2, suggesting a possible osmoregulation impairment due to the high conductivity of effluents (Glazier and Sparks, 1997; Cornet et al., 2009).

Most of the target pharmaceuticals were detected below chronic toxicity thresholds with the exception of sulfamethoxazole, diclofenac and propranolol which were measured at concentrations exceeding PNEC (Predicted No Effect Concentration) according to Orias and Perrodin (2013). Calculated PNEC for sulfamethoxazole is $0.59 \mu \mathrm{g} / \mathrm{L}$ and it was found at concentrations 19.6 and 6.8 times higher in CAS and $\mathrm{CASO}_{3}$ loop effluents, respectively. A slight genotoxic effect of sulfamethoxazole was observed at a concentration higher than $500 \mathrm{mg} / \mathrm{L}$ in human lymphocyte culture (Abou-Eisha et al., 2004). Once again, it is unlikely, that sulfamethoxazole could have accounted for the slight genotoxic effect observed in sperm of CAS-exposed gammarids. Genotoxicity measured in spermatozoa of Gammarus fossarum exposed to the undiluted CAS was not very high when compared to DNA damage level monitored in Gammarus fossarum caged in a river downstream a wastewater treatment plant discharge using conventional activated sludge treatment, that reached a 21\% TI value (Lacaze et al., 2011c). Moreover, the fact that effluents CAS and $\mathrm{CASO}_{3}$ loop would be diluted after discharge in the river, the risk of possible genotoxic effects on organisms in receiving water is likely to decrease to a large extent. In Stalter et al. (2010) and Cao et al. (2009), tertiary ozonation resulted
A

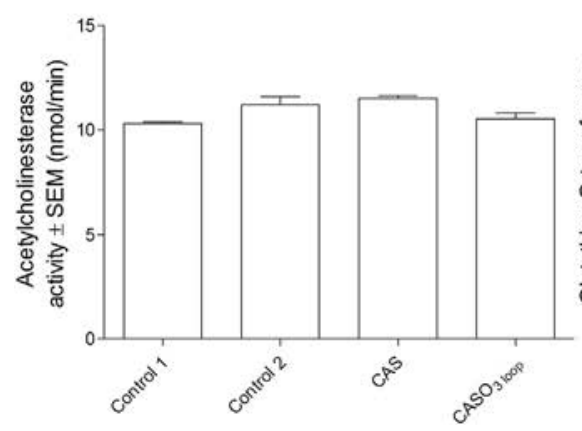

B

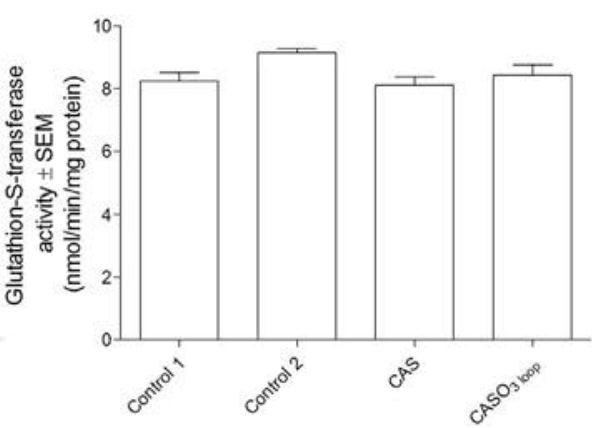

C

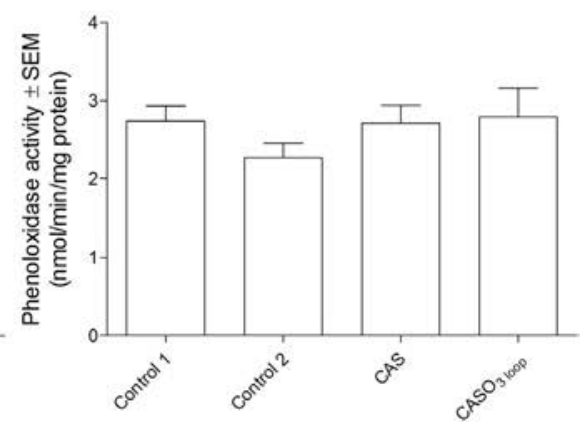

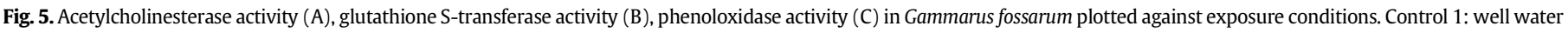

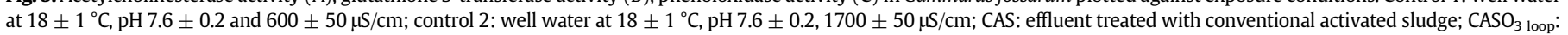
effluent treated with ozonated conventional activated sludge ( $9.4 \mathrm{mg} \mathrm{O}_{3} / \mathrm{L}$ ). 
in an increased DNA damage compared to the conventional activated sludge treatment, possibly related to genotoxic ozonation by-products. In the present study, no difference of genotoxic potential between the ozonated sludge treated effluent $\left(\mathrm{CASO}_{3}\right.$ loop$)$ and conventional activated sludge treated effluent (CAS) was observed. This suggests that ozonation of activated sludge does not proceed with the formation of more genotoxic compounds than the reference conventional treatment or as well that the genotoxic by-products possibly formed upon ozone action are assimilated by the biological treatment.

In Lacaze et al. (2011b), 30\% Gammarus fossarum embryos showed developmental abnormalities when DNA damage level in parent spermatozoa exposed to the model genotoxicant methyl methanesulfonate was above $50 \% \mathrm{TI}$. In the present study, over $90 \%$ of embryos were malformed, although DNA damage in parent spermatozoa remained low after exposure to CAS and $\mathrm{CASO}_{3}$ loop effluents (15.5\% and $10.7 \%$ TI respectively). This indicates that embryonic developmental abnormalities must have resulted from other compounds than genotoxicants present in effluents. Sundelin and Eriksson (1998) found that the percentage of malformed embryos in female amphipods Monoporeia affinis from Baltic Sea increased the closer to industrial wastewater treatment plant discharges the sampling station was.

For the evaluation of reproduction impairment in Gammarus fossarum, the occurred molt stages in exposure groups were compared to the embryo stages monitored in the marsupium of female gammarids according to Geffard et al. (2010). Since molt cycle and reproductive cycle in Gammarus fossarum females occur concurrently (Subramoniam, 2000), a molt cycle corresponds to an embryonic stage (as previously illustrated in Fig. 2) and a discrepancy between them may be interpreted as a toxic effect (Geffard et al., 2010). Conductivity in wastewaters can vary from 50 to $1500 \mu \mathrm{S} / \mathrm{cm}$ in domestic wastewaters and up to $10,000 \mu \mathrm{S} / \mathrm{cm}$ in industrial wastewaters (Water Environmental Federation, 2007). In the present study, conductivity had no significant effect on the molt cycle or the embryonic developmental stages but females exposed to the higher conductivity control (control 2) showed a slight but significant decrease in embryo number per female compared to the control 1 with a lower conductivity around $600 \mu \mathrm{S} / \mathrm{cm}$. When females were exposed to the $\mathrm{CAS}_{\text {or }} \mathrm{CASO}_{3}$ loop effluents the molt cycle was retarded and the total number of embryos and of mature oocytes were significantly reduced compared to the control. Exposure to CAS and $\mathrm{CASO}_{3}$ loop effluent seems to have impaired the molt and the reproductive cycle in most of the exposed female gammarids. Chemical analysis showed that after CAS and $\mathrm{CASO}_{3}$ loop treatments most of surfactants were at concentrations below the limit of quantification, and only LAS C10 (a linear alkylbenzene sulfonate) and stepanquat GA 90 were detectable in the range of 7.1 to $10 \mu \mathrm{g} / \mathrm{L}$. Previous studies showed that $\mathrm{EC}_{50}$ value for Ceriodaphnia dubia immobilization after $48 \mathrm{~h}$ exposure to LAS was $5.96 \mathrm{mg} / \mathrm{L}$ and $\mathrm{EC}_{10}$ for reproduction after 7 days exposure was $1.18 \mathrm{mg} / \mathrm{L}$, being respectively 596 and 118 times higher than LAS concentration $(10 \mu \mathrm{g} / \mathrm{L})$ measured in $\mathrm{CAS}$ and $\mathrm{CASO}_{3}$ loop effluent in the present study (OECD SIDS, 2005; Ivankovic and Hrenovic, 2010), therefore LAS is unlikely responsible for observed reproduction impairing effects. Since sulfamethoxazole concentration found in $\mathrm{CAS}$ and $\mathrm{CASO}_{3}$ loop effluent was respectively 11 and $4 \mu \mathrm{g} / \mathrm{L}$, and that chronic exposure for 30 days of Daphnia magna to $10 \mu \mathrm{g} / \mathrm{L}$ sulfamethoxazole did not affect reproduction nor growth (Flaherty and Dodson, 2005), the high effects observed on reproductive output in both gammarid exposure groups were likely not induced by this compound. Diclofenac concentration measured in $\mathrm{CAS}$ and $\mathrm{CASO}_{3}$ loop effluents was 383 and $174 \mathrm{ng} / \mathrm{L}$, respectively. Diclofenac $\mathrm{EC}_{50}$ regarding immobilization of Daphnia magna after 48 h exposure was estimated at $68 \mathrm{mg} / \mathrm{L}$ (Cleuvers, 2003) and the lowest observed effect concentration for reproduction inhibition in Ceriodaphnia dubia was $2 \mathrm{mg} / \mathrm{L}$ diclofenac (Santos et al., 2010). It leads to the assumption that effects observed on reproduction and growth in gammarids exposed to CAS and $\mathrm{CASO}_{3}$ loop effluents cannot be conceivably attributed to the low residual diclofenac concentrations. The same can be said for propranolol, recovered in $\mathrm{CAS}$ and $\mathrm{CASO}_{3}$ loop effluents at higher concentrations, respectively 2.5 and 1.9 times higher than the PNEC value estimated at around $50 \mathrm{ng} / \mathrm{L}$, even if a seven day-exposure to propranolol was shown to alter reproduction in Ceriodaphnia dubia at a 2 fold propanolol concentration $(250 \mu \mathrm{g} / \mathrm{L})$ than those measured in the present study (Huggett et al., 2002). Beside the possible contribution to the observed toxicity of other single compounds, mixture effects should also be considered (Richardson and Ternes, 2011). Cleuvers (2004) exposed Daphnia magna in the acute test to a mixture of non-toxic concentrations of diclofenac, ibuprofen, naproxen and acetylsalicylic acid. Exposure to the mixture (diclofenac at $17 \mathrm{mg} / \mathrm{L}$, ibuprofen at $25.3 \mathrm{mg} / \mathrm{L}$, naproxen at $41.6 \mathrm{mg} / \mathrm{L}$ and acetylsalicylic acid at $22 \mathrm{mg} / \mathrm{L}$ ) resulted in $\mathrm{EC}_{50}$ as high as $\mathrm{EC}_{50}$ predicted by concentration addition. Such an additive effect, although here shown at concentrations of pharmaceuticals much higher than measured in $\mathrm{CAS}$ and $\mathrm{CASO}_{3}$ loop, is commonly described, and has to be taken into account for complex mixtures as wastewaters (Farre et al., 2008).

The reproductive success of gammarids was significantly reduced after exposure to $\mathrm{CAS}$ or $\mathrm{CASO}_{3}$ loop effluents and no significant difference between the two exposure groups were found, although micropollutant concentrations were different in both effluents. This is in accordance with the study of Chung et al. (2008), who found a reduction in embryo number per female in the amphipod Melita plumulosa exposed in polluted rivers compared to unpolluted ones. Additionally, organic matter content in the effluents might also have contributed to the observed toxicity since Englert et al. (2013) showed that wastewater negatively affected macroinvertebrate feeding as well as abundance and leaf litter decomposition. According to Coulaud et al. (2015), reproductive alterations as impaired molting cycle and reduced fertility and fecundity of female gammarids can significantly affect population dynamics. More than $90 \%$ of the embryos produced in the marsupium of females exposed to $\mathrm{CAS}$ or $\mathrm{CASO}_{3}$ loop effluent exhibited developmental malformations (although pharmaceuticals content in $\mathrm{CASO}_{3}$ loop is lower than in CAS). Thus, both residual pollutant mixture and organic matter in both effluents reduced significantly the fecundity of female gammarids and affected embryo development. Cold and Forbes (2004) showed that pulse exposure ( $1 \mathrm{~h}$ ) to $50 \mathrm{ng} / \mathrm{L}$ of the pyrethroid insecticide esfenvalerate reduced the number of offspring in Gammarus pulex to $60 \%$ of the control and a decreased reproductive output was still observable 2 weeks later. The impairment of molt cycle, fecundity and induction of embryonic malformations in gammarids seem to be sensitive and ecologically relevant endpoints to reveal residual toxicity of treated effluents consisting of a mixture of low concentrated micropollutants since they may have potential long-term effects on exposed populations (Jobling et al., 1998; Lewis and Galloway, 2009; Santos et al., 2010).

\section{Conclusion}

This study shows that exposure of Gammarus fossarum to an effluent treated by conventional activated sludge and an effluent treated by ozonated conventional activated sludge, consisting of a mixture of micropollutants and residual organic matter, is appropriate to determine residual toxicity. No significant difference in any of the measured endpoints was observed between the two tested effluents (with and without ozonation of wastewater), although the concentrations of quantified micropollutants were not similar and generally lower for the ozonated CAS treatment. The most sensitive endpoints, which should be considered for toxicity evaluation of effluents, were the impairment of molt cycle and fecundity, the induction of embryonic malformations and to a lesser extent sperm genotoxicity.

Further experiments carried out in situ by caging gammarids directly in receiving waters for long exposure duration should improve the risk assessment of such effluent treatments. 


\section{Funding}

This research was financially supported by the French Ministry of Economy, Industry and Digital (grant number 132906048) within the framework of the Project TRIUMPH (TReatIng Urban Micropollutants and Pharmaceuticals in wastewaters) labelled and managed by the European Eureka Cluster ACQUEAU.

\section{Conflict of interest}

The authors declare that they have no conflict of interest.

\section{Acknowledgements}

The experimental pilot program was hosted into the SIPIBEL field observatory supported by Rhone-Mediterranean Corsica water agency, The Rhône Alpes Region and other partners.

\section{References}

Abou-Eisha, A., Marcos, R., Creus, A., 2004. Genotoxicity studies on the antimicrobial drug sulfamethoxazole. Mutat. Res. 564, 51-56.

Baig, S., Choubert, J.M., Martin Ruel, S., Esperanza, M., Budzinski, H., Miege, C., Coquery, M., 2010. Ozone disinfection of urban wastewater at full-scale. Impact on Persistent Micropollutants. IOA International Conference Geneva, Switzerland (April 28-30, 2010. Proceedings Paper 7.3)

Bergé, A., Giroud, B., Wiest, L., Domenjoud, B., Gonzalez-Ospina, A., Vulliet, E., 2016. Development of a multiple-class analytical method based on the use of synthetic matrices for the simultaneous determination of commonly used commercial surfactants in wastewater by liquid chromatography-tandem mass spectrometry. J. Chromatogr. A 1450, 64-75.

Berger, E., Haase, P., Oetken, M., Sundermann, A., 2016. Field data reveal low critical chemical concentrations for river benthic invertebrates. Sci. Total Environ. 544, 864-873.

Besse, J.P., Coquery, M., Lopes, C., Chaumot, A., Budzinski, H., Labadie, P., Geffard, O., 2013. Caged Gammarus fossarum (Crustacea) as a robust tool for the characterization of bioavailable contamination levels in continental waters: towards the determination of threshold values. Water Res. 47, 650-660.

Braun, A., Hoffmann, J.A., Meister, M., 1998. Analysis of the Drosophila host defense in domino mutant larvae, which are devoid of hemocytes. Proc. Natl. Acad. Sci. 95 14337-14342.

Bundschuh, M., Schulz, R., 2011. Population response to ozone application in wastewater: an on-site microcosm study with Gammarus fossarum (Crustacea: Amphipoda). Ecotoxicology 20, 466-473.

Cao, N., Yang, M., Zhang, Y., Hu, J., Ike, M., Hirotsuji, J., Matsui, H., Inoue, D., Sei, K., 2009. Evaluation of wastewater reclamation technologies based on in vitro and in vivo bioassays. Sci. Total Environ. 407, 1588-1597.

Chen, X., Richard, J., Liu, Y., Dopp, E., Tuerk, J., Bester, K., 2012. Ozonation products of triclosan in advanced wastewater treatment. Water Res. 46, 2247-2256.

Chonova, T., Keck, F., Labanowski, J., Montuelle, B., Rimet, F., Bouchez, A., 2016. Separate treatment of hospital and urban wastewaters: a real scale comparison of effluents and their effect on microbial communities. Sci. Total Environ. 542, 965-975.

Chung, P.P., Hyne, R.V., Mann, R.M., Ballard, J.W.O., 2008. Genetic and life-history trait variation of the amphipod Melita plumulosa from polluted and unpolluted waterways in eastern Australia. Sci. Total Environ. 403, 222-229.

Cleuvers, M., 2003. Aquatic ecotoxicity of pharmaceuticals including the assessment of combination effects. Toxicol. Lett. 142, 185-194.

Cleuvers, M., 2004. Mixture toxicity of the anti-inflammatory drugs diclofenac, ibuprofen, naproxen, and acetylsalicylic acid. Ecotoxicol. Environ. Saf. 59, 309-315.

Cold, A., Forbes, V.E., 2004. Consequences of a short pulse of pesticide exposure for survival and reproduction of Gammarus pulex. Aquat. Toxicol. 67, 287-299.

Cornet, S., Biard, C., Moret, Y., 2009. Variation in immune defence among populations of Gammarus pulex (Crustacea: Amphipoda). Oecologia 159, 257-269.

Coulaud, R., Geffard, O., Vigneron, A., Queau, H., Francois, A., Chaumot, A., 2015. Linking feeding inhibition with reproductive impairment in Gammarus confirms the ecological relevance of feeding assays in environmental monitoring. Environ. Toxicol. Chem. 34, 1031-1038.

Devaux, A., Fiat, L., Gillet, C., Bony, S., 2011. Reproduction impairment following paternal genotoxin exposure in brown trout (Salmo trutta) and Arctic charr (Salvelinus alpinus). Aquat. Toxicol. 101, 405-411.

Domingues, I., Agra, A.R., Monaghan, K., Soares, A.M.V.M., Nogueira, A.J.A., 2010. Cholinesterase and glutathione-S-transferase activities in freshwater invertebrates as biomarkers to assess pesticide contamination. Environ. Toxicol. Chem. 29, 5-18

Ellman, G.L., Courtney, K.D., Andres, V., Featherstone, R.M., 1961. A new rapid colorimetric determination of acetylcholinesterase activity. Biochem. Pharmacol. 7, 88-95

Englert, D., Zubrod, J.P., Schulz, R., Bundschuh, M., 2013. Effects of municipal wastewater on aquatic ecosystem structure and function in the receiving stream. Sci. Total Environ. 454-455, 401-410.
European Commission, 2000. Directive 2000/60/EC of the European Parliament and of the Council establishing a framework for Community action in the field of water policy. Off. J. Eur. Communities 327, 1-72.

European Commission, 2013. Directive 2013/39/EU of the European Parliament and of the Council amending Directives 2000/60/EC and 2008/105/EC as regards priority substances in the field of water policy. Off. J. Eur. Union 226, 1-17.

Farre, M., Perez, S., Kantiani, L., Barcelo, D., 2008. Fate and toxicity of emerging pollutants, their metabolites and transformation products in the aquatic environment. Trends Anal. Chem. 27, 991-1007.

Fent, K., Weston, A.A., Caminada, D., 2006. Ecotoxicology of human pharmaceuticals. Aquat. Toxicol. 76, 122-159.

Flaherty, C.M., Dodson, S.I., 2005. Effects of pharmaceuticals on Daphnia survival, growth, and reproduction. Chemosphere 61, 200-207.

Fulton, M.H., Key, P.B., 2001. Acetylcholinesterase inhibition in estuarine fish and invertebrates as an indicator of organophosphorus insecticide exposure and effects. Environ. Toxicol. Chem. 20, 37-45.

Geffard, O., Xuereb, B., Chaumot, A., Geffard, A., Biagianti, S., Noel, C., Abbaci, K., Garric, J., Charmantier, G., Charmantier-Daures, M., 2010. Ovarian cycle and embryonic development in Gammarus fossarum: application for reproductive toxicity assessment. Environ. Toxicol. Chem. 29, 2249-2259.

Glazier, D.S., Sparks, B.L., 1997. Energetics of amphipods in ion-poor waters: stress resistance is not invariably linked to low metabolic rates. Funct. Ecol. 11, 126-128.

Glazier, D.S., Horne, M.T., Lehman, M.E., 1992. Abundance, body composition and reproductive output of Gammarus minus (Crustacea: Amphipoda) in ten cold springs differing in $\mathrm{pH}$ and ionic content. Freshw. Biol. 28, 149-163.

Habig, W.H., Pabst, M.J., Jakoby, W.B., 1976. Glutathione S-transferase AA from rat liver. Arch. Biochem. Biophys. 175, 710-716.

Huggett, D.B., Brooks, B.W., Peterson, P., Foran, C., Schlenk, D., 2002. Toxicity of a select beta adrenergic receptor-blocking pharmaceuticals (B-Blockers) on aquatic organisms. Arch. Environ. Contam. Toxicol. 43, 229-235.

Hyne, R.V., Maher, W.A., 2003. Invertebrate biomarkers: links to toxicosis that predict population decline. Ecotoxicol. Environ. Saf. 54, 366-374.

Ivankovic, T., Hrenovic, J., 2010. Surfactants in the environment. Arch. Ind. Hyg. Toxicol. $61,95-110$.

Janssens, L., Stoks, R., 2013. Exposure to a widespread non-pathogenic bacterium magnifies sublethal pesticide effects in the damselfly Enallagma cyathigerum: from the suborganismal level to fitness-related traits. Environ. Pollut. 177, 143-149.

Jha, A., 2008. Ecotoxicological applications and significance of the comet assay. Mutagenesis 23, 207-221.

Jobling, S., Nolan, M., Tyler, C.R., Brighty, G., Sumpter, J.P., 1998. Widespread sexual disruption in wild fish. Environ. Sci. Technol. 32, 2498-2506.

Karaouzas, I., Cotou, E., Albanis, T.A., Kamarianos, A., Skoulikidis, N.T., Giannakou, U., 2011. Bioassays and biochemical biomarkers for assessing olive mill and citrus processing wastewater toxicity. Environ. Toxicol. 26, 669-676.

Kümmerer, K., 2009. The presence of pharmaceuticals in the environment due to human use - present knowledge and future challenges. J. Environ. Manag. 90, 2354-2366.

Lacaze, E., Geffard, O., Bony, S., Devaux, A., 2010. Genotoxicity assessment in the amphipod Gammarus fossarum by use of the alkaline comet assay. Mutat. Res. 700, 32-38.

Lacaze, E., Devaux, A., Jubeaux, G., Mons, R., Bony, S., Garric, J., Geffard, A., Geffard, O., 2011a. DNA damage in caged Gammarus fossarum amphipods: a tool for freshwater genotoxicity assessment. Environ. Pollut. 159, 1682-1691.

Lacaze, E., Devaux, A., Jubeaux, G., Mons, R., Gardette, M., Bony, S., Garric, J., Geffard, O., 2011b. DNA damage in Gammarus fossarum sperm as a biomarker of genotoxic pressure: intrinsic variability and reference level. Sci. Total Environ. 409, 3230-3236.

Lacaze, E., Geffard, O., Goyet, D., Bony, S., Devaux, A., 2011c. Linking genotoxic responses in Gammarus fossarum germ cells with reproduction impairment, using the comet assay. Environ. Res. 111, 626-634.

Lewis, C., Galloway, T., 2009. Reproductive consequences of paternal genotoxin exposure in marine invertebrates. Environ. Sci. Technol. 43, 928-933.

Li, W.C., 2014. Occurrence, sources, and fate of pharmaceuticals in aquatic environment and soil. Environ. Pollut. 187, 193-201.

Lowry, O.H., Rosebrough, N.J., Farr, A.L., Randall, R.J., 1951. Protein measurement with the Folin phenol reagent. J. Biol. Chem. 193, 167-170.

Luo, Y, Guo, W., Ngo, H.H., Nghiem, L.D., Hai, F. Zhang J. Liang S, Wang X.C. 2014. A review on the occurrence of micropollutants in the aquatic environment and their fate and removal during wastewater treatment. Sci. Total Environ. 473-474, 619-641.

MacNeil, C., Dick, J.T.A., Bisby, E.W., Elwood, R.W., Montgomery, W.I., Gibbins, C.N., Kelly, D.W., 2002. The validity of the Gammarus: Asellus ratio as an index of organic pollution: abiotic and biotic influences. Water Res. 36, 75-84.

Magdeburg, A., Stalter, D., Schlüsener, M., Ternes, T., Oehlmann, J., 2014. Evaluating the efficiency of advanced wastewater treatment: target analysis of organic contaminants and (geno-) toxicity assessment tell a different story. Water Res. 50, 35-47.

Mazurova, E., Hilscherova, K., Sidlova-Stepankova, T., Köhler, H.R., Triebskorn, R., Jungmann, D., Giesy, J.P., Blaha, L., 2010. Chronic toxicity of contaminated sediments on reproduction and histopathology of the crustacean Gammarus fossarum and relationship with the chemical contamination and in vitro effects. J. Soils Sediments 10, 423-433.

Misik, M., Knasmueller, S., Ferk, F., Cichna-Markl, M., Grummt, T., Schaar, H., Kreuzinger, N., 2011. Impact of ozonation on the genotoxic activity of tertiary treated municipal wastewater. Water Res. 45, 3681-3691.

Morrissey, C.A., Mineau, P., Devries, J.H., Sanchez-Bayo, F., Liess, M., Cavallaro, M.C., Liber, K., 2015. Neonicotinoid contamination of global surface waters and associated risk to aquatic invertebrates: a review. Environ. Int. 74, 291-303.

Newman, M.C., Clements, W.H., 2008. Ecotoxicology: A Comprehensive Treatment. CRC Press, Taylor \& Francis Group, Boca Raton, Florida, USA 
OECD SIDS, 2005. Linear alkylbenzene sulfonate (LAS). Initial Assessment Report for 20th SIAM, Paris, France, pp. 1-357 (UNEP Publications).

Oehlmann, J., Schulte-Oehlmann, U., Bachmann, J., Oetken, M., Lutz, I., Kloas, W., Ternes, T.A., 2006. Bisphenol A induces superfeminization in the ramshorn snail Marisa cornuarietis (Gastropoda: Prosobranchia) at environmentally relevant concentrations. Environ. Health Perspect. 114 (Suppl. 1), 127-133.

Orias, F., Perrodin, Y., 2013. Characterization of the ecotoxicity of hospital effluents: a review. Sci. Total Environ. 454-455, 250-276.

Perrodin, Y., Bazin, C., Orias, F., Wigh, A., Bastide, T., Berlioz-Barbier, A., Vulliet, E., Wiest, L., 2016. A posteriori assessment of ecotoxicological risks linked to building a hospital. Chemosphere 144, 440-445.

Peschke, K., Geburzi, J., Köhler, H.R., Wurm, K., Triebskorn, R., 2014. Invertebrates as indicators for chemical stress in sewage-influenced stream systems: toxic and endocrine effects in gammarids and reactions at the community level in two tributaries of Lake Constance, Schussen and Argen. Ecotoxicol. Environ. Saf. 106, 115-125.

Petrie, B., Barden, R., Kasprzyk-Hordern, B., 2015. A review on emerging contaminants in wastewaters and the environment: current knowledge, understudied areas and recommendations for future monitoring. Water Res. 72, 3-27.

Pöckl, M., 1992. Effects of temperature, age and body size on moulting and growth in the freshwater amphipods Gammarus fossarum and G. roeseli. Freshw. Biol. 27, 211-225.

Pöckl, M., Timischl, W., 1990. Comparative study of mathematical models for the relationship between water temperature and brood development time of Gammarus fossarum and G. roeseli (Crustacea: Amphipoda). Freshw. Biol. 23, 433-440.

Pöckl, M., Webb, B.W., Sutcliffe, D.W., 2003. Life history and reproductive capacity of Gammarus fossarum and G. roeseli (Crustacea: Amphipoda) under naturally fluctuating water temperatures: a simulation study. Freshw. Biol. 48, 53-66.

Richardson, S.D., Ternes, T.A., 2011. Water analysis: emerging contaminants and current issues. Anal. Chem. 83, 4614-4648.

Santos, H.M.L.M.L., Araujo, A.N., Fachini, A., Pena, A., Delerue-Matos, C., Montenegro, M.C.B.S.M., 2010. Ecotoxicological aspects related to the presence of pharmaceuticals in the aquatic environment. J. Hazard. Mater. 175, 45-95.

Schirling, M., Jungmann, D., Ladewig, V., Nagel, R., Triebskorn, R., Köhler, H.-R., 2005. Endocrine effects in Gammarus fossarum (Amphipoda): influence of wastewater effluents, temporal variability, and spatial aspects on natural populations. Arch. Environ. Contam. Toxicol. 49, 53-61.

Schneider, I., Oehlmann, J., Oetken, M., 2015. Impact of an estrogenic sewage treatment plant effluent on life-history traits of the freshwater amphipod Gammarus pulex. J. Environ. Sci. Health, Part A: Tox. Hazard. Subst. Environ. Eng. 50, 272-281.
Schwarzenbach, R.P., Escher, B.I., Fenner, K., Hofstetter, T.B., Johnson, C.A., von Gunten, U, Wehrli, B., 2006. The challenge of micropollutants in aquatic systems. Science 313, 1072-1077.

Silva, E., Rajapakse, N., Kortenkamp, A., 2002. Something from "Nothing" - eight weak estrogenic chemicals combined at concentrations below NOECs produce significant mixture effects. Environ. Sci. Technol. 36, 1751-1756.

Stalter, D., Magdeburg, A., Oehlmann, J., 2010. Comparative toxicity assessment of ozone and activated carbon treated sewage effluents using an in vivo test battery. Water Res. 44, 2610-2620.

Subramoniam, T., 2000. Crustacean ecdysteriods in reproduction and embryogenesis Comp. Biochem. Physiol. C 125, 135-156.

Sugumaran, M., 2002. Comparative biochemistry of eumelanogenesis and the protective roles of phenoloxidase and melanin in insects. Pigment Cell Res. 15, 2-9.

Sundelin, B., Eriksson, A.K., 1998. Malformations in embryos of the deposit-feeding amphipod Monoporeia affinis in the Baltic Sea. Mar. Ecol. Prog. Ser. 171, 165-180.

Turja, R., Guimaraes, L., Nevala, A., Kankaanpää, H., Korpinen, S., Lehtonen, K.K., 2014. Cumulative effects of exposure to cyanobacteria bloom extracts and benzo[a]pyrene on antioxidant defence biomarkers in Gammarus oceanicus (Crustacea: Amphipoda). Toxicon 78, 68-77.

Vulliet, E., Tournier, M., Vauchez, A., Wiest, L., Baudot, R., Lafay, F., Kiss, A., Cren-Olivé, C., 2014. Survey regarding the occurrence of selected organic micropollutants in the ground waters of overseas departments. Environ. Sci. Pollut. Res. 21, 7512-7521.

Water Environmental Federation, 2007. Characterization and sampling of wastewater. Operation of municipal wastewater treatment plants. WEF Manual of Practice No. 11, sixth ed. WEF Press, New York (chapter 17).

Wick, A., Fink, G., Joss, A., Siegrist, H., Ternes, T.A., 2009. Fate of beta blockers and psychoactive drugs in conventional wastewater treatment. Water Res. 43 (4), 1060-1074.

Wigh, A., Devaux, A., Brosselin, V., Gonzalez-Ospina, A., Domenjoud, B., Ait-Aissa, S. Creusot, N., Gosset, A., Bazin, C., Bony, S., 2016. Proposal to optimize ecotoxicological evaluation of wastewater treated by conventional biological and ozonation processes. Environ. Sci. Pollut. Res. 23, 3008-3017.

Xuereb, B., Chaumot, A., Mons, R., Garric, J., Geffard, O., 2009a. Acetylcholinesterase activity in Gammarus fossarum (Crustacea Amphipoda) intrinsic variability, reference levels, and a reliable tool for field surveys. Aquat.Toxicol. 93, 225-233. 